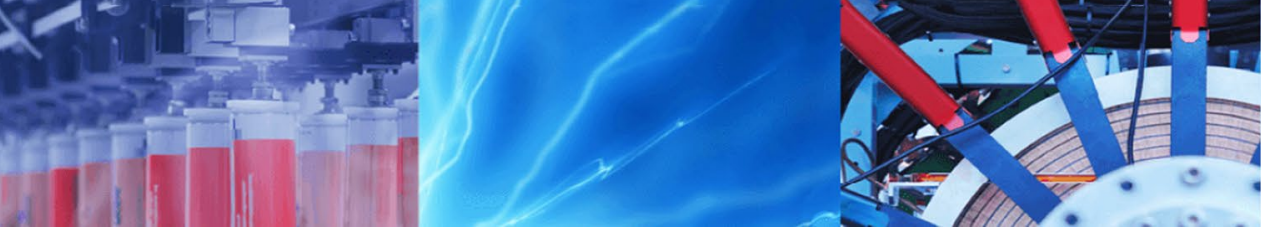

Research Article

\title{
Assessment of groundwater quality and determination of hydrochemical evolution of groundwater in Shillong, Meghalaya (India)
}

\author{
Chakresh K. Jain ${ }^{1}$ - Sanjay K. Sharma ${ }^{2}$. Surya Singh ${ }^{3}$
}

Received: 11 August 2020 / Accepted: 21 December 2020 / Published online: 8 January 2021

(c) The Author(s) 2021 OPEN

\begin{abstract}
Deterioration of surface water quality in various parts of India due to increasing urbanization has led to the extensive usage of groundwater for various domestic and irrigation needs, thereby raising concerns over its quality. However, there are very few studies focussing over the issue of groundwater quality in North-Eastern region of India. In order to make an assessment of the quality of groundwater for drinking and irrigation purposes, this study was carried out in Shillong - the Capital City of Meghalaya State in North-East India during pre-monsoon and post-monsoon seasons of 2018. Standard sampling and analytical procedures were followed for groundwater quality assessment. Minimal variation was observed in the water quality of pre- and post-monsoon seasons. However, the study found that groundwater samples are having acidic $\mathrm{pH}$ and presence of nitrate is also reported. Some of the samples also showed the presence of mercury, nickel, and cadmium. The presence of these contaminants could be attributed to the industrial activities in the state. Overall, the groundwater quality was found suitable for drinking and irrigation purposes after conventional treatment. Hydrochemical studies further inferred that groundwater properties in the region are influenced by the rock weathering along with the atmospheric precipitation.
\end{abstract}

Keywords Drinking water quality $\cdot$ Groundwater $\cdot$ Hydrochemical mechanism · India · Irrigation $\cdot$ Shillong

\section{Introduction}

Periodic water quality assessment of surface and groundwater is necessary for the well-being of ecosystem in general, and for the human society in particular. Declining surface water resources along with the increasing levels of pollution have rendered the use of groundwater mandatory in various parts of the globe [1,2]. Being the largest user of the groundwater in the world, India fulfils its $85 \%$ drinking water needs and more than $60 \%$ of the irrigation requirements through groundwater resources $[3$, 4]. Therefore, it is of utmost importance to look after the groundwater resources on regular basis so that required action, if any, could be taken well in time. The chemical constituents of the water are affected by natural as well as anthropogenic factors. Increasing use of chemicals (fertilizers and pesticides) for the agricultural practices is also one of the anthropogenic causes for the deterioration of both surface and ground water quality [5]. Therefore, it is necessary to keep a check on the water quality in order to ensure wellbeing of the people.

Considering the importance of groundwater and its quality degradation due to urbanization and increasing pollution, many researchers have discussed the groundwater chemistry and its human health risk assessment across the globe [6-9]. Not only the heavy metals and

$\triangle$ Surya Singh, suryasingh.er@gmail.com | ${ }^{1}$ Centre for Science and Environmental Research, Roorkee 247667, India. ${ }^{2} \mathrm{NIH}-\mathrm{Centre}$ for Flood Management Studies, Dispur 781006, India. ${ }^{3}$ ICMR - National Institute for Research in Environmental Health, Bhopal 462030, India. 
bacterial contamination, excess amount of basic water quality parameters such as $\mathrm{pH}$, total dissolved solids, and nitrate have also been reported in groundwater owing to unsustainable use and indiscriminate subsurface discharge of various pollutants $[4,7]$. In order to understand the effects of these factors onto the health and agriculture, many researchers have employed various statistical and multivariate statistical analyses tools [1]. As water quality index is a comprehensive approach to assess the quality of groundwater, Su et al. have used entropy weighted water quality index [10]. Use of Fuzzy method has also been reported by the researchers for the easy and accurate estimation of water quality [7].

Groundwater is affected by various other factors as well, such as geological features, precipitation pattern, rock weathering mechanism, river system, oxidation-reduction, evaporation, sorption, and exchange reactions [11, 12]. The water quality of Shillong is also affected by various such processes. Meghalaya, a north-eastern hilly state, is one of the 29 states of India bounded to the south by Bangladeshi divisions, and to the north and east by Assam, India. This state is the wettest region of India, receiving approximately $12,000 \mathrm{~mm}$ rain in a year. Therefore, it is obvious that the groundwater chemistry of the area would show the influence of the rainfall pattern of the area. The present study was carried out in Shillong, which was known as the 'Scotland of the East' during British period owing to the presence of rolling hills around the town [13]. Although this region has been pollution free, the population explosion and urbanization have led to various environmental problems recently. Surface water scarcity is among one of those problems which is of serious concern due to topography of the region [14]. Due to shortage of the clean surface water, now the pressure is increasing onto the groundwater resources, and hence, it was considered necessary to have an assessment of the quality of the same. In this manuscript, the assessment and suitability of the groundwater in the Shillong region for drinking and irrigation purposes are detailed.

\section{Materials and methods}

\subsection{Study area}

This study was carried out in Shillong which is the capital city of Meghalaya State in India (Fig. 1). Shillong is also the district headquarter of East Khasi Hills $\left(2748 \mathrm{~km}^{2}\right)$, which is
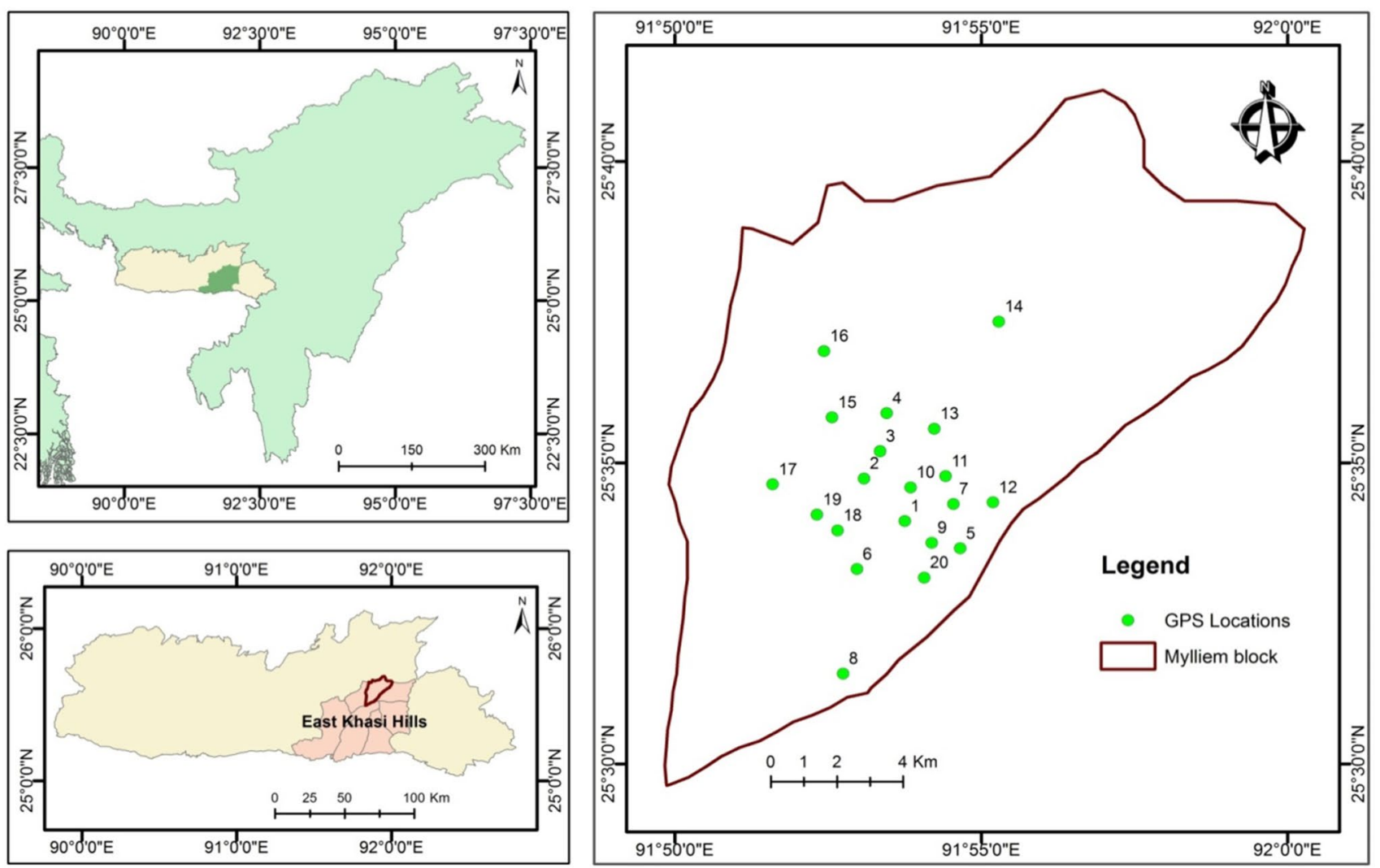

Fig. 1 Location of Shillong and sampling sites

\section{SN Applied Sciences}




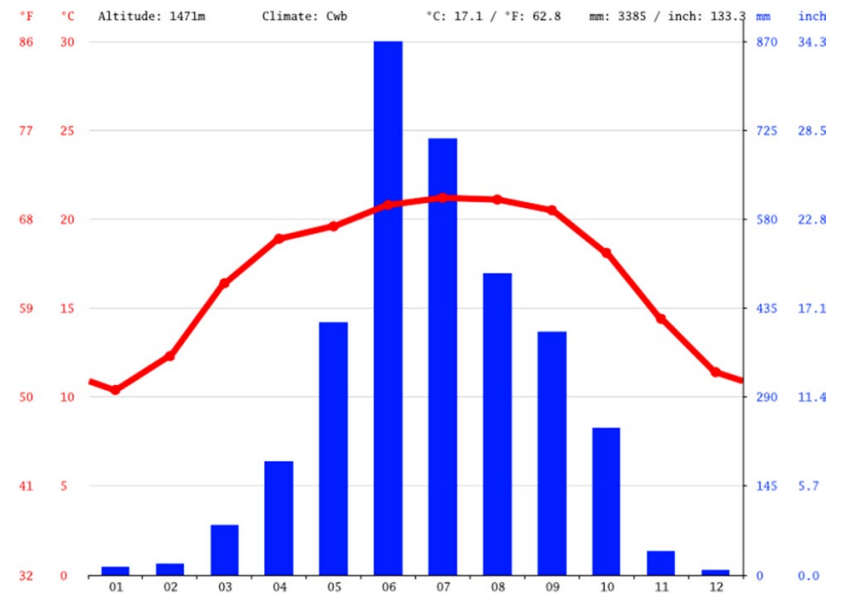

Fig. 2 The annual climate distribution (rainfall and temperature) map of Shillong. Source: https://en.climate-data.org/asia/india/ meghalaya/shillong-24618/\#climate-graph

one of the seven districts of Meghalaya State. The climate of the area ranges from temperate humid to subtropical humid with temperature varying from $1.7{ }^{\circ} \mathrm{C}$ to $24^{\circ} \mathrm{C}$ [14]. Annual climate distribution of the district is shown in Fig. 2. It depicts that the highest rainfall in the area is received in the month of June and July, though none of the month is completely dry. The highest temperature is also reported in the same months, thus making the climate humid. The south-west monsoon, which originates from the Bay of Bengal, has large effect on the weather pattern in Meghalaya. It results in heavy rainfall of more than $12,000 \mathrm{~mm}$ in various districts of the state. Mawsynram, which receives about $12,270 \mathrm{~mm}$ rainfall, is the wettest place on the earth owing to the specific geographical and climatological conditions. Shillong is also characterized by the presence of a number of rivers, such as Umtrew, Umiam, Umkhen in the northern parts and Umiew (Shella), Umngot, Umngi (Balat) in the southern part. The rivers present in the northern part of the district drain into the Brahmaputra River (India), while southern rivers drain into the Surma River (Bangladesh) [14].

Precambrian rocks of gneissic composition are the dominant rock types in the study area. Basically, these rocks form the base of the overlying Shillong rocks. Another rock type which is present in the study area is quartzite. These quartzites attained their final form after the metamorphosis, though originally these are of sedimentary origin, as evident by the presence of bedding and ripple marks. As the terrain in Shillong is mountainous and undulating, the groundwater resources in the area are influenced by the topography, presence of rock fractures, and weathering zones. Generally, the groundwater in the region is found in the weathered and fractured zone of quartzite, under the water table condition. Groundwater resources have been reported in the form of springs, seepages, wells, and bore wells. The property of retaining water in the bore wells is also influenced by the underlying rocks, as it has been seen that metabasic rocks provide better inflow of groundwater. Consequently, the wells over the metabasic rocks have water availability throughout the year, while the wells over the quartzites become devoid of water in dry season. The hydrogeological map of East Khasi Hills District of Meghalaya is shown in Fig. 3, which shows that the highest groundwater potential is in the coarse sandstone, silt, shale, and clay formations, though their occurrence is limited. The majority of the area is occupied by the quartzite and granite rocks having groundwater potential of $5-15 \mathrm{~m}^{3} / \mathrm{hr}$.

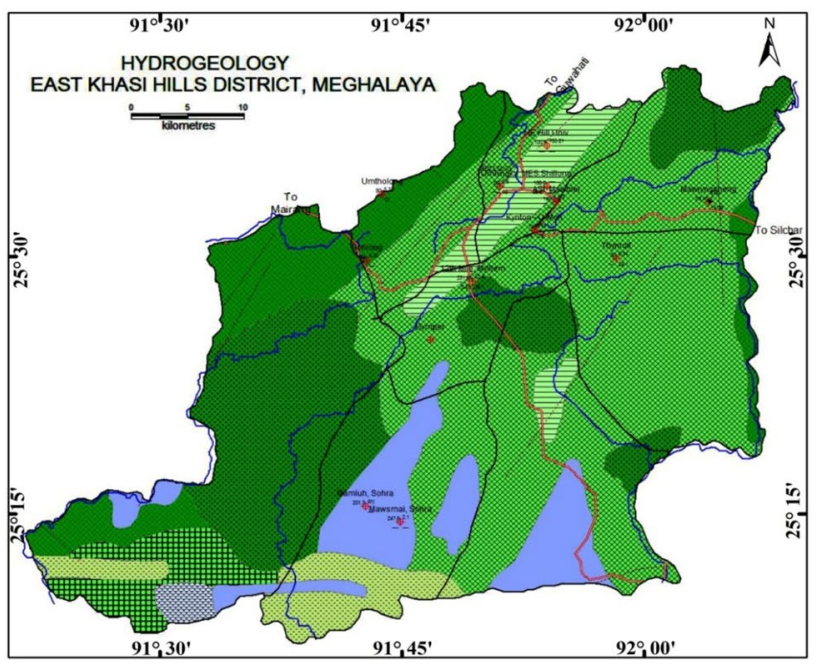

\section{LEGEND}

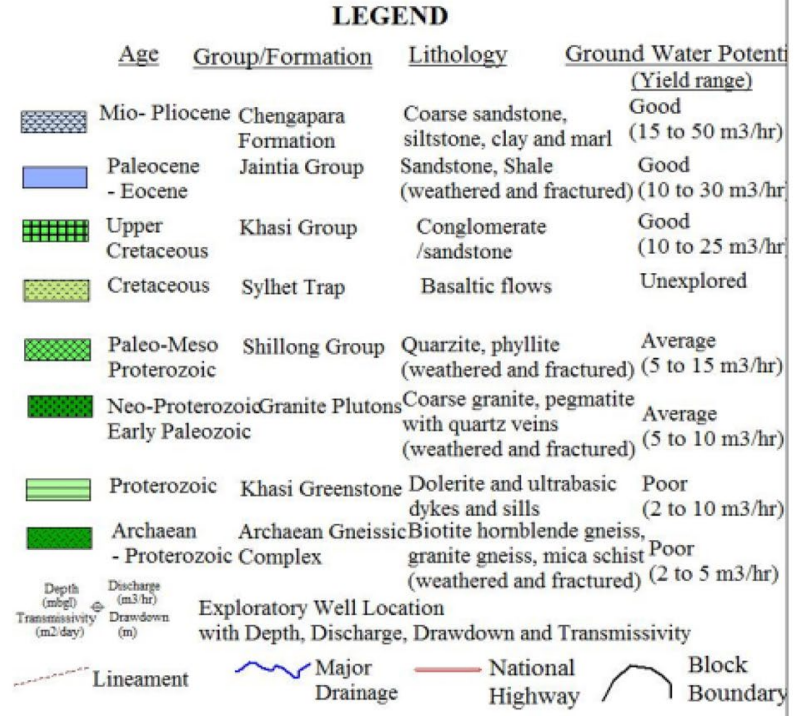

Fig. 3 Hydrogeological map of East Khasi Hills District, Meghalaya. Source: CGWB 2013 [14] 


\subsection{Sampling and preservation}

Twenty ground water samples were collected each during pre- and post-monsoon seasons of 2018. The details of the sampling locations are shown in Table 1. The sampling points are located in the middle of the basin as the northeast and southwest parts of the study region were forests/hilly areas and hence not accessible (Fig. 1). The samples were collected from bore wells in clean polyethylene bottles, and acid was added in order to preserve $[4,15,16]$. The water samples for trace element analysis were collected in acid leached polyethylene bottles and preserved by adding ultra-pure nitric acid ( $5 \mathrm{~mL} /$ lit.). All the samples were stored in sampling kits maintained at $4{ }^{\circ} \mathrm{C}$ and brought to the laboratory for detailed physicochemical analysis. The distribution of sampling locations is shown in Fig. 1.

\subsection{Analysis}

All the chemicals used for the analysis were of analytical grade (Merck). To analyse the metal content in the samples, standard solutions of metal ions were procured from Merck, Germany. De-ionized water was used for the analysis. Samples for metal analysis were filtered using
$0.45 \mu \mathrm{m}$ membrane filter. Glasswares and all other containers used for trace element analysis were thoroughly cleaned using appropriate methods [4].

Prescribed standard methods were used for the analysis of physico-chemical parameters $[15,16]$. The analysis of anions and cations was carried out using Ion Chromatograph (IC) (Make: Metrohm, Model 930). Metal analysis was done in Inductively Coupled Plasma Mass Spectroscopy (ICP-MS) (Make: PerkinElmer, Model: ELAN DRC-e). For bicarbonate analysis, Potentiometric Auto Titrator (Model 888 system) was used. Analytical precision was $<5 \%$ for all the analytes (anions and cations) and metals, and accuracy was $<5 \%$. Alkalinity was determined by setting the end point using Potentiometric Auto Titrator, and finally, bicarbonate was calculated using inbuilt formula in the system (titration accuracy $<2.0 \%$, precision $<1.5 \%$ and systemic error $< \pm 0.010 \mathrm{~mL}$ ). Errors in ionic balance were $<5 \%$ for each analysis. Ionic balance was calculated by the formula $\left[\left\{\left(\mathrm{TZ}^{+}-\mathrm{TZ}^{-}\right) /\left(\mathrm{TZ}^{+}+\mathrm{TZ}^{-}\right)\right\} \times 100\right]$, thus establishing the reliability and quality of the analytical results. Calibration curves of standard solutions for the respective constituents were drawn for the quantification of chemical constituents. AQUACHEM 2011.1 software was used for drawing the Piper plot.

Table 1 Groundwater sampling locations in Shillong

\begin{tabular}{|c|c|c|c|c|c|c|c|}
\hline \multirow[t]{2}{*}{ S. No } & \multirow[t]{2}{*}{ Location } & \multicolumn{2}{|c|}{ Geographical coordinates } & \multirow[t]{2}{*}{ Source } & \multirow[t]{2}{*}{ Depth (m) } & \multirow[t]{2}{*}{ Yield (L/hr) } & \multirow[t]{2}{*}{ Land use } \\
\hline & & Latitude & Longitude & & & & \\
\hline 1 & Gordon road, Bhagyakul, Laitumkhrah & $25^{\circ} 34^{\prime} 2^{\prime \prime}$ & $91^{\circ} 53^{\prime} 45.1^{\prime \prime}$ & Bore well & 198 & 2500 & Domestic \\
\hline 2 & Jail road & $25^{\circ} 34^{\prime} 44.6^{\prime \prime}$ & $91^{\circ} 53^{\prime} 5.1^{\prime \prime}$ & Bore well & 50 & 5000 & Domestic \\
\hline 3 & Forest colony & $25^{\circ} 35^{\prime} 11.6^{\prime \prime}$ & $91^{\circ} 53^{\prime} 20.9^{\prime \prime}$ & Bore well & 61 & 1500 & Domestic \\
\hline 4 & Mawlaidatbaki pata block A & $25^{\circ} 35^{\prime} 82.1^{\prime \prime}$ & $91^{\circ} 53^{\prime} 45.7^{\prime \prime}$ & Bore well & 84 & 4800 & Domestic \\
\hline 5 & $\begin{array}{l}\text { Evangelical free church, Demthring, PO: } \\
\text { Madanryting }\end{array}$ & $25^{\circ} 33^{\prime} 34.9^{\prime \prime}$ & $91^{\circ} 54^{\prime} 39.3^{\prime \prime}$ & Bore well & 46 & 2000 & Domestic \\
\hline 6 & Happy valley & $25^{\circ} 33^{\prime} 14.1^{\prime \prime}$ & $91^{\circ} 52^{\prime} 58.3^{\prime \prime}$ & Bore well & 69 & 1500 & Domestic \\
\hline 7 & Law U Sib, Divine grace cottage & $25^{\circ} 33^{\prime} 47.0^{\prime \prime}$ & $91^{\circ} 54^{\prime} 46.7^{\prime \prime}$ & Bore well & 97 & 2000 & Domestic \\
\hline 8 & Laitkor, Lumheh Mawrie & $25^{\circ} 31^{\prime} 4.20^{\prime \prime}$ & $91^{\circ} 52^{\prime} 46.78^{\prime \prime}$ & Bore well & 100 & 2500 & Commercial \\
\hline 9 & Nongrim hills & $25^{\circ} 33^{\prime} 58.1^{\prime \prime}$ & $91^{\circ} 54^{\prime} 3.8^{\prime \prime}$ & Bore well & 245 & 5000 & Commercial \\
\hline 10 & Laitumkhrah & $25^{\circ} 34^{\prime} 16.8^{\prime \prime}$ & $91^{\circ} 53^{\prime} 48.2^{\prime \prime}$ & Bore well & 198 & 4800 & Commercial \\
\hline 11 & Fruit garden & $25^{\circ} 33^{\prime} 56.2^{\prime \prime}$ & $91^{\circ} 53^{\prime} 45.9^{\prime \prime}$ & Bore well & 143 & 11,250 & Commercial \\
\hline 12 & Lapalang dong parmaw & $25^{\circ} 34^{\prime} 16.6^{\prime \prime}$ & $91^{\circ} 55^{\prime} 37.7^{\prime \prime}$ & Bore well & 125 & 4500 & Domestic \\
\hline 13 & Bellefonte, Lumshyiap & $25^{\circ} 35^{\prime} 33.9^{\prime \prime}$ & $91^{\circ} 54^{\prime} 14.0^{\prime \prime}$ & Bore well & 37 & 2000 & Domestic \\
\hline 14 & Mawtawar Lummawsing & $25^{\circ} 37^{\prime} 20.5^{\prime \prime}$ & $91^{\circ} 55^{\prime} 17.2^{\prime \prime}$ & Bore well & 183 & 500 & Domestic \\
\hline 15 & Mawlai Syllaikariah & $25^{\circ} 35^{\prime} 45.1^{\prime \prime}$ & $91^{\circ} 52^{\prime} 33.9^{\prime \prime}$ & Bore well & 100 & 2000 & Domestic \\
\hline 16 & Mawiong umjapung block nongneng-A & $25^{\circ} 36^{\prime} 51.1^{\prime \prime}$ & $91^{\circ} 52^{\prime} 25.9^{\prime \prime}$ & Bore well & 132 & 2000 & Domestic \\
\hline 17 & 3rd Mile upper Shillong & $25^{\circ} 34^{\prime} 38.7^{\prime \prime}$ & $91^{\circ} 51^{\prime} 35.6^{\prime \prime}$ & Bore well & 92 & 1200 & Domestic \\
\hline 18 & Howell road near shiv mandir, Laban & $25^{\circ} 33^{\prime} 52.7^{\prime \prime}$ & $91^{\circ} 52^{\prime} 39.1^{\prime \prime}$ & Bore well & 43 & 2000 & Domestic \\
\hline 19 & Behind Shillong times & $25^{\circ} 34^{\prime} 8.6^{\prime \prime}$ & $91^{\circ} 52^{\prime} 19.1^{\prime \prime}$ & Bore well & 85 & 1000 & Domestic \\
\hline 20 & Nongthymmai, Dum Dum & $25^{\circ} 33^{\prime} 48.5^{\prime \prime}$ & $91^{\circ} 54^{\prime} 36.8^{\prime \prime}$ & Bore well & 41 & 3000 & Domestic \\
\hline
\end{tabular}




\section{Results and discussion}

\subsection{Groundwater quality evaluation for drinking purposes}

Groundwater quality estimation in Shillong was done for all the necessary organoleptic and physico-chemical parameters. The metals were analysed only for the samples collected during pre-monsoon. Tested values were compared with the standard values given by Bureau of Indian Standards (BIS) and World Health Organization (WHO) $[17,18]$ (Tables $2-3$ ). It can be seen that among the general parameters, nitrate $\left(\mathrm{NO}_{3}{ }^{-}\right)$is the only parameter for which the value is exceeding the acceptable limit. Another parameter of interest is $\mathrm{pH}$. As per the BIS and $\mathrm{WHO}$, the acceptable $\mathrm{pH}$ values for drinking purposes should lie within the range of 6.5-8.5. It was seen that none of the samples were having $\mathrm{pH}$ value beyond 8.5; however, 12 samples recorded the value below 6.5, minimum being the 3.5. It indicates acidic contamination in the groundwater. One of the reasons for this acidic contamination might be the influence of geological factors of the area. Meghalaya is known for the high deposits of coal [19], and Indian coal is characterized by the high sulphide pyrite content [20]. Moreover, the geology

Table 2 General parameters with respect to drinking water quality in Shillong and comparison with standards $[17,18]$

\begin{tabular}{|c|c|c|c|c|c|c|c|c|c|}
\hline \multirow{2}{*}{$\begin{array}{l}\text { Water qual- } \\
\text { ity param- } \\
\text { eters }\end{array}$} & \multicolumn{2}{|c|}{ WHO standard* } & \multicolumn{2}{|c|}{ Indian standard (BIS)* } & \multicolumn{3}{|c|}{$\begin{array}{l}\text { Water quality in } \\
\text { Shillong* }\end{array}$} & \multirow{2}{*}{$\begin{array}{l}\text { Number of samples } \\
\text { beyond acceptable } \\
\text { limit }\end{array}$} & \multirow{2}{*}{$\begin{array}{l}\text { Number of samples } \\
\text { beyond permissible } \\
\text { limit }\end{array}$} \\
\hline & $\begin{array}{l}\text { Max. } \\
\text { desirable } \\
\text { limit }\end{array}$ & $\begin{array}{l}\text { Max. per- } \\
\text { missible } \\
\text { limit }\end{array}$ & Acceptable limit & Permissible limit & Min & Max & Mean & & \\
\hline \multicolumn{10}{|l|}{ Pre-monsoon } \\
\hline $\mathrm{pH}$ & - & $6.5-8.5$ & $6.5-8.5$ & - & 3.5 & 8.0 & 5.95 & 12 & 0 \\
\hline Conductivity & - & - & - & - & 12.2 & 759 & 214 & - & - \\
\hline TDS & 500 & 1500 & 500 & 2000 & 7.8 & 486 & 137 & 0 & 0 \\
\hline Alkalinity & - & - & 200 & 600 & Nil & 96 & 21 & 0 & 0 \\
\hline Hardness & 100 & 500 & 200 & 600 & 6.3 & 156 & 53 & 0 & 0 \\
\hline Sodium & - & - & - & - & 0.5 & 59 & 13 & - & - \\
\hline Potassium & - & - & - & - & 0.3 & 27 & 4.2 & - & - \\
\hline Calcium & 75 & - & 75 & 200 & 1.99 & 44 & 15 & 0 & 0 \\
\hline Magnesium & 50 & 150 & 30 & 100 & 0.20 & 16 & 3.6 & 0 & 0 \\
\hline Chloride & 250 & - & 250 & 1000 & 0.43 & 81 & 21 & 0 & 0 \\
\hline Sulphate & - & - & 200 & 400 & 0.09 & 39 & 9.9 & 0 & 0 \\
\hline Nitrate & - & - & 45 & - & 0.14 & 186 & 31 & 5 & - \\
\hline Fluoride & 1.0 & 1.5 & 1 & 1.5 & 0.02 & 0.42 & 0.09 & 0 & 0 \\
\hline Boron & - & 2.4 & 0.5 & 1 & 0.01 & 0.03 & 0.02 & 0 & 0 \\
\hline \multicolumn{10}{|l|}{ Post-monsoon } \\
\hline $\mathrm{pH}$ & - & $6.5-8.5$ & $6.5-8.5$ & - & 4.1 & 7.8 & 6.1 & 9 & 0 \\
\hline Conductivity & - & - & - & - & 20.9 & 710 & 183 & - & - \\
\hline TDS & 500 & 1500 & 500 & 2000 & 13.4 & 454 & 117 & 0 & 0 \\
\hline Alkalinity & - & - & 200 & 600 & Nil & 108 & 21 & 0 & 0 \\
\hline Hardness & 100 & 500 & 200 & 600 & 9.3 & 144 & 43 & 0 & 0 \\
\hline Sodium & - & - & - & - & 0.57 & 55 & 12 & - & - \\
\hline Potassium & - & - & - & - & 0.36 & 24 & 3.55 & - & - \\
\hline Calcium & 75 & - & 75 & 200 & 2.59 & 33 & 12 & 0 & 0 \\
\hline Magnesium & 50 & 150 & 30 & 100 & 0.40 & 16 & 3.17 & 0 & 0 \\
\hline Chloride & 250 & - & 250 & 1000 & 0.46 & 75 & 17 & 0 & 0 \\
\hline Sulphate & - & - & 200 & 400 & 0.11 & 31 & 7.35 & 0 & 0 \\
\hline Nitrate & - & - & 45 & - & 0.03 & 165 & 25 & 2 & - \\
\hline Fluoride & 1.0 & 1.5 & 1 & 1.5 & 0.01 & 0.34 & 0.07 & 0 & 0 \\
\hline Boron & - & 2.4 & 0.5 & 1 & 0.01 & 0.03 & 0.02 & 0 & 0 \\
\hline
\end{tabular}

${ }^{*}$ All values are in $\mathrm{mg} / \mathrm{L}$, except for $\mathrm{pH}$ and conductivity $(\mu \mathrm{S} / \mathrm{cm})$ 
Table 3 Presence of metals with respect to drinking water quality in Shillong district and comparisons with the standards [17, 18]

\begin{tabular}{|c|c|c|c|c|c|c|c|c|c|}
\hline \multirow[t]{2}{*}{ Metals } & \multicolumn{2}{|c|}{ WHO standard* } & \multicolumn{2}{|c|}{ Indian standard (BIS)* } & \multicolumn{3}{|c|}{$\begin{array}{l}\text { Water quality in } \\
\text { Shillong* }\end{array}$} & \multirow{2}{*}{$\begin{array}{l}\text { Number of } \\
\text { samples beyond } \\
\text { acceptable limit }\end{array}$} & \multirow{2}{*}{$\begin{array}{l}\text { Number of samples } \\
\text { beyond permissible } \\
\text { limit }\end{array}$} \\
\hline & $\begin{array}{l}\text { Max. } \\
\text { desirable } \\
\text { limit }\end{array}$ & $\begin{array}{l}\text { Max. per- } \\
\text { missible } \\
\text { limit }\end{array}$ & Acceptable limit & Permissible limit & Min & Max & Mean & & \\
\hline Iron (Fe) & - & - & 300 & - & 47 & 6342 & 986 & 7 & - \\
\hline Manganese (Mn) & - & 500 & 100 & 300 & 10 & 464 & 178 & 12 & 5 \\
\hline Copper (Cu) & - & 1000 & 50 & 1500 & 3 & 311 & 52 & 6 & 0 \\
\hline Chromium (Cr) & - & - & 50 & - & 0.2 & 4.7 & 1.0 & 0 & - \\
\hline Lead $(\mathrm{Pb})$ & - & 50 & 10 & - & 0.3 & 10 & 3.2 & 0 & - \\
\hline Arsenic (As) & - & 50 & 10 & 50 & 0.06 & 4.89 & 0.9 & 0 & 0 \\
\hline Mercury (Hg) & - & 1 & 1 & - & 0.07 & 9.45 & 0.9 & 3 & - \\
\hline Nickel (Ni) & - & - & 20 & - & 1.5 & 54 & 7.6 & 1 & - \\
\hline Zinc (Zn) & - & 5000 & 5000 & 15,000 & 19 & 3356 & 552 & 0 & 0 \\
\hline Cadmium (Cd) & - & 5 & 3 & - & 0.3 & 10 & 3.2 & 8 & - \\
\hline
\end{tabular}

${ }^{*}$ All values are in $\mu \mathrm{g} / \mathrm{L}$

of Meghalaya is also characterized by the presence of high iron content [14]. Iron sulphide upon oxidation forms the sulphuric acid (Eqs. 1 and 2) [21], which might increase the acidity of groundwater. Another reason might be the contamination from acid mine drainage [22].

$4 \mathrm{FeS}_{2}+11 \mathrm{O}_{2} \rightarrow 2 \mathrm{Fe}_{2} \mathrm{O}_{3}+8 \mathrm{SO}_{2}$

$2 \mathrm{SO}_{2}+2 \mathrm{H}_{2} \mathrm{O}+\mathrm{O}_{2} \rightarrow 2 \mathrm{H}_{2} \mathrm{SO}_{4}$

High concentration of nitrate in samples collected from well number $5,7,12,15$, and 20 (Table 1 ) is also indicative of the unhygienic conditions near these wells and contamination due to municipal sewage as it was found flowing through the open drains. There was no diffuse contamination from fertilizers [5]. Contamination due to sewage is of serious concern and needs to be looked upon as it is difficult to restore groundwater quality, once contaminated [7]. The spot value maps for $\mathrm{pH}$ and nitrate are presented in Fig. 4.

Analysis of water quality results indicates that most of the sites are common where $\mathrm{pH}$ and nitrate values are persistently beyond the acceptable range. High values of nitrate can be attributed to the faecal contamination through the open municipal drains [5].

Further, the analytical results of metals reveal that water quality of the area is affected by the presence of iron (Fe), manganese $(\mathrm{Mn})$, mercury $(\mathrm{Hg})$, nickel $(\mathrm{Ni})$, and cadmium (Cd) to the considerable extent. Among these elements, presence of Fe and $\mathrm{Mn}$ can be attributed to local geogenic causes. Low $\mathrm{pH}$ in the groundwater might be one of the reasons for the occurrence of high amount of Fe and $\mathrm{Mn}$.
It is a fact that acidic $\mathrm{pH}$ results in more dissolution of $\mathrm{Fe}$ and $\mathrm{Mn}$ [23]. Since in the groundwater of Shillong, $\mathrm{pH}$ values are far below the acceptable range and water is acidic (Table 2), the excess amount of Fe and $\mathrm{Mn}$ is evident. In such conditions, iron occurs in the form of $\mathrm{Fe}^{+2}$. Such water might result in rusty colour upon bringing it into the atmosphere, owing to the oxidation from $\mathrm{Fe}^{+2}$ to $\mathrm{Fe}^{+3}$. The occurrence of Fe and $\mathrm{Mn}$ is not much harmful because of their natural presence in human body [4, 24, 25]. However, dissolved iron $\left(\mathrm{Fe}^{+2}\right)$ results in growth of iron bacteria within the bore wells, which might create problems of unpleasant taste and odour in the bore well waters. Therefore, it is advisable to disinfect the bore wells and plumbing fixtures at regular time intervals. Occurrence of $\mathrm{Hg}, \mathrm{Ni}$, and $\mathrm{Cd}$ is undoubtedly a reason of concern, considering the harmful impacts onto the human body. These three elements are generally of industrial origin. Though very few samples are exceeding the acceptable limit, the presence of these metals shows that there is seepage either from point or non-point sources, which is contaminating the groundwater. Discharge from open municipal drains could also be one of the reasons for the occurrence of metals. Moreover, the inappropriate disposal from industries manufacturing dry cell batteries, light bulbs, and other fluorescent items also contributes toward the groundwater contamination [22].

\subsection{Groundwater quality evaluation for irrigation purposes}

For agricultural purposes, it is necessary to evaluate groundwater samples as water of suitable quality is one of the prime requirements for enhancing the crop growth 

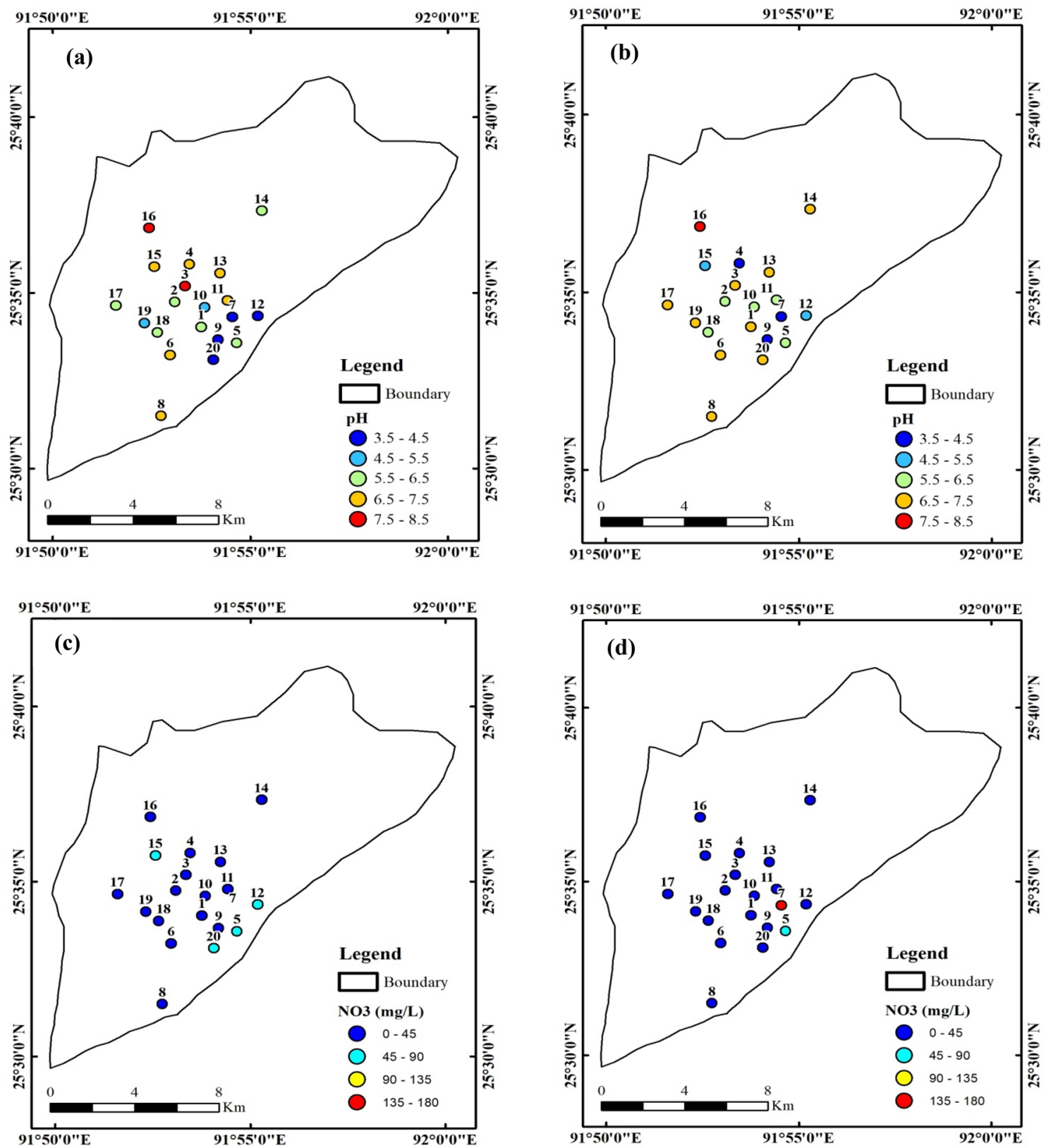

Fig. 4 Spot value maps for the parameters beyond acceptable limits a pH (pre-monsoon), b pH (post-monsoon), c nitrate (pre-monsoon), and $\mathbf{d}$ nitrate (post-monsoon)

and soil properties [26]. With this purpose, chemical parameters were assessed to determine the quality of water for irrigation purposes (Table 4). Total dissolved solid (TDS) is one of the most important parameters, and its value for all the samples is below the $1000 \mathrm{mg} / \mathrm{L}$, the maximum value being $454.4 \mathrm{mg} / \mathrm{L}$. It represents that the soil is of non-saline nature. Electrical conductivity is another parameter for representing salinity. High conductivity is not considered good as it might lead to high salinity. Table 4 shows that $70 \%$ samples are having conductivity $<250 \mu \mathrm{S} / \mathrm{cm}$, while $25 \%$ lies in the range of $250-750 \mu \mathrm{S} /$ $\mathrm{cm}$. Therefore, this water is suitable for its use for irrigation purposes in terms of salinity hazard.

Apart from salinity, another important factor to consider for irrigation purposes is the alkalinity. Sodium concentration in the soil affects the sodium absorption ratio. High concentration of sodium results in alkali hazard in the soil. In such conditions, clay particles tend to absorb sodium ion and displace the magnesium and calcium ions. It results in saturation of cation exchange complex with sodium and further leads to dispersion of clay particles, thereby altering the soil structure [4]. Permeability of the 
Table 4 Irrigation water quality parameters

\begin{tabular}{|c|c|c|c|c|}
\hline \multirow[t]{2}{*}{ Parameters } & \multirow[t]{2}{*}{ Range } & \multirow[t]{2}{*}{ Classification } & \multicolumn{2}{|c|}{$\begin{array}{l}\text { Number of samples in } \\
\text { Shillong }\end{array}$} \\
\hline & & & Pre-monsoon & $\begin{array}{l}\text { Post- } \\
\text { mon- } \\
\text { soon }\end{array}$ \\
\hline \multirow[t]{4}{*}{ Total dissolved solid (TDS) (mg/L) [27] } & $<1000$ & Non-saline & 20 & 20 \\
\hline & $1000-3000$ & Slightly saline & 0 & 0 \\
\hline & $3000-10,000$ & Moderately saline & 0 & 0 \\
\hline & $>10,000$ & Very saline & 0 & 0 \\
\hline \multirow[t]{5}{*}{ Salinity hazard $(E C)(\mu S / c m)[27]$} & $<250$ & Excellent & 14 & 16 \\
\hline & $250-750$ & Good & 5 & 4 \\
\hline & $750-2000$ & Permissible & 1 & 0 \\
\hline & $2000-3000$ & Doubtful & 0 & 0 \\
\hline & $>3000$ & Unsuitable & 0 & 0 \\
\hline \multirow[t]{4}{*}{ Alkalinity hazard (SAR) [28] } & $<10$ & Excellent & 20 & 20 \\
\hline & $10-18$ & Good & 0 & 0 \\
\hline & $18-26$ & Doubtful & 0 & 0 \\
\hline & $>26$ & Unsuitable & 0 & 0 \\
\hline \multirow[t]{5}{*}{ Percent sodium (\%Na) [29] } & $<20$ & Excellent & 3 & 4 \\
\hline & $20-40$ & Good & 8 & 5 \\
\hline & $40-60$ & Permissible & 8 & 9 \\
\hline & $60-80$ & Doubtful & 1 & 2 \\
\hline & $>80$ & Unsuitable & 0 & 0 \\
\hline \multirow[t]{3}{*}{ Permeability index (PI) [29] } & $<80$ & Good & 18 & 16 \\
\hline & $80-100$ & Moderate & 0 & 2 \\
\hline & $100-120$ & Poor & 2 & 2 \\
\hline \multirow[t]{2}{*}{ Kelly's ratio (KR) [30] } & $<1$ & Suitable & 16 & 17 \\
\hline & $>1$ & Unsuitable & 4 & 3 \\
\hline \multirow[t]{2}{*}{ Magnesium ratio (MR) [31] } & $>50 \%$ & Suitable & 2 & 2 \\
\hline & $<50 \%$ & Unsuitable & 18 & 18 \\
\hline \multirow[t]{3}{*}{ Residual sodium carbonate (RSC) [32] } & $<1.25$ & Suitable & 20 & 20 \\
\hline & $1.25-2.5$ & Marginally suitable & 0 & 0 \\
\hline & $>2.5$ & Unsuitable & 0 & 0 \\
\hline \multirow[t]{2}{*}{ Corrosivity ratio (CR) [33] } & $<1$ & Suitable & 11 & 8 \\
\hline & $>1$ & Unsuitable & 9 & 12 \\
\hline
\end{tabular}

soil may also get affected by such an exchange of cations [34]. In the present study, alkalinity hazard is less than 10 , which indicates that water is suitable for agricultural purposes. As per the permeability index also, majority of the samples lie within the suitable range. Percent $\mathrm{Na}$ and Kelly's ratio indicates the sodium content in water. For both these parameters, the values were found within the suitable range (Table 4).

US salinity diagram was plotted for assessing the sodium and salinity hazard, as shown in Fig. 5. A total of $45 \%$ pre-monsoon samples lie in C1-S1 category, while $25 \%$ samples lie in C2-S1 category. Similarly, among the post-monsoon samples, $50 \%$ lie in C1-S1 category and $20 \%$ lie in C2-S1 category. C1-S1 category represents the low salinity and low sodium hazard, while C2-S1 category represents the medium salinity and low sodium hazard $[28,35]$. Thus, this analysis corroborates that the groundwater is fit for irrigation purposes. However, it is to be noted that one pre-monsoon sample lies in C3-S1 category as well which indicates high salinity and low sodium hazard. This particular condition may be attributed to local factors. Plants having sufficient salt tolerance may be preferred for cultivation using this groundwater [4].

Magnesium ratio and residual sodium carbonate are also important parameters to determine the alkalinity hazard in the water to be used for irrigation purposes. Kumar et al. reported that alkalinity may increase if the water contains high magnesium content which ultimately affects the yield of the crop [36]. It is intriguing to note that out of the 20 samples in pre-monsoon and post-monsoon seasons 


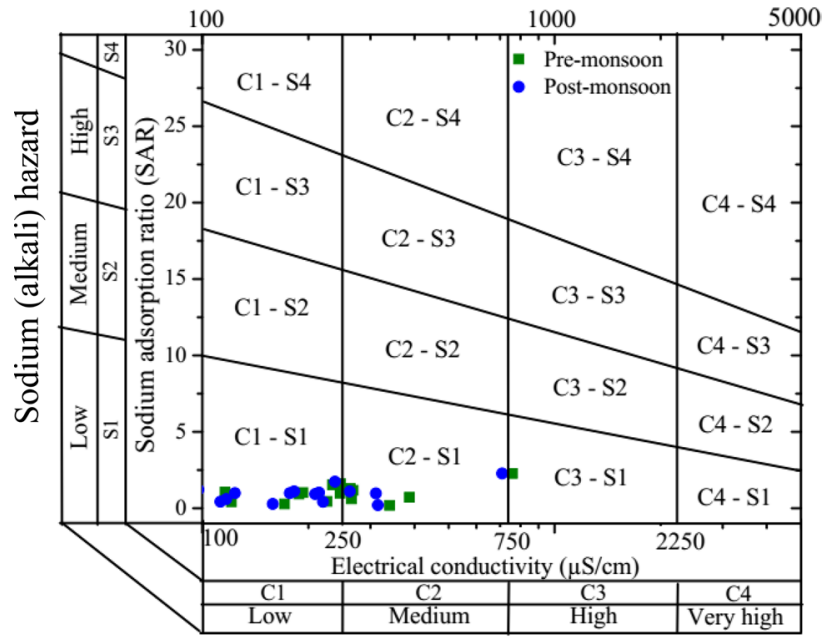

Salinity hazard

Fig. 5 US salinity diagram for classification of groundwater for irrigation purposes

each, only 2 samples in each seasons were found suitable as far as magnesium ratio is concerned (Table 4). However, in such a case, the soil to be used for cultivation may be treated with some organic/inorganic acidifying materials. Another important parameter of interest is residual sodium carbonate (RSC), which is usually assessed to check the suitability of irrigation water for clayey soil. This is so because clayey soils possess high cation exchange capacity. It can be seen in Table 4 that all the samples are found to be suitable, having RSC values less than 1.25 [32].

Corrosivity ratio is the ratio of alkaline earths to saline salts in groundwater [33] and is usually calculated for determining the suitability of groundwater for its transportation and distribution through metallic pipes. In case water is found to be corrosive for the pipes, polyvinylchloride (PVC) pipes may be utilized. In the Shillong water, almost half of the samples were found to be corrosive (Table 4), and therefore, use of PVC pipes is advised.

Thus, it can be seen that water quality of the Shillong is suitable for agricultural purposes in respect of all the parameters except magnesium ratio and corrosivity ratio.

\subsection{Groundwater chemistry and hydrochemical mechanisms}

\subsubsection{Correlation among hydrochemical variables}

Pearson's correlation matrix is a good method to establish the relationship among various variables. The correlation matrix for pre-monsoon and post-monsoon seasons (Table 5 and Table 6, respectively) shows the inter-relationship among 13 hydrochemical parameters. Excess amount of salt which is dissolved in water (TDS) increases the electricity conducting ability of water, thereby establishing the correlation with EC. Positive correlation of $\mathrm{EC}$ also exists with the $\mathrm{Na}, \mathrm{K}, \mathrm{Ca}, \mathrm{Cl}$, etc., in both pre-monsoon and post-monsoon seasons. Further, strong correlation is also seen among the TDS and $\mathrm{Na}$, $\mathrm{K}, \mathrm{Ca}, \mathrm{Cl}$. Positive correlation is also seen between total hardness (TH) and $\mathrm{Ca}$ and $\mathrm{Mg}$. Since hardness is caused by the carbonates and bicarbonates of $\mathrm{Ca}$ and $\mathrm{Mg}$, positive correlation among them is evident. It is interesting to note that $\mathrm{Cl}$ is strongly correlated with $\mathrm{NO}_{3}$ in both the seasons. This might be due to the influence of sewage contamination as it was found flowing through the open drains near the sampling sites.
Table 5 Pearson's correlation matrix for groundwater samples-Pre-monsoon ${ }^{\#}$

\begin{tabular}{llllllllllllll}
\hline & $\mathrm{pH}$ & $\mathrm{EC}$ & $\mathrm{TDS}$ & $\mathrm{TA}$ & $\mathrm{TH}$ & $\mathrm{Na}$ & $\mathrm{K}$ & $\mathrm{Ca}$ & $\mathrm{Mg}$ & $\mathrm{Cl}$ & $\mathrm{SO}_{4}$ & $\mathrm{NO}_{3}$ & $\mathrm{~F}$ \\
\hline $\mathrm{pH}$ & 1 & & & & & & & & & & & \\
$\mathrm{EC}$ & -0.22 & 1 & & & & & & & & & & \\
$\mathrm{TDS}$ & -0.22 & 1.00 & 1 & & & & & & & & & \\
$\mathrm{TA}$ & 0.75 & 0.19 & 0.19 & 1 & & & & & & & & \\
$\mathrm{TH}$ & 0.32 & 0.79 & 0.79 & 0.71 & 1 & & & & & & & \\
$\mathrm{Na}$ & -0.49 & $\mathbf{0 . 9 0}$ & $\mathbf{0 . 9 0}$ & -0.21 & 0.45 & 1 & & & & & & \\
$\mathrm{~K}$ & -0.29 & $\mathbf{0 . 9 0}$ & $\mathbf{0 . 9 0}$ & -0.06 & 0.53 & $\mathbf{0 . 8 6}$ & 1 & & & & & \\
$\mathrm{Ca}$ & 0.29 & $\mathbf{0 . 8 0}$ & $\mathbf{0 . 8 0}$ & 0.65 & $\mathbf{1 . 0 0}$ & 0.51 & 0.60 & 1 & & & & \\
$\mathrm{Mg}$ & 0.28 & 0.50 & 0.50 & 0.64 & 0.79 & 0.20 & 0.22 & 0.59 & 1 & & & \\
$\mathrm{Cl}$ & -0.46 & $\mathbf{0 . 9 0}$ & $\mathbf{0 . 9 0}$ & -0.17 & 0.52 & $\mathbf{0 . 9 7}$ & $\mathbf{0 . 8 1}$ & 0.57 & 0.27 & 1 & & & \\
$\mathrm{SO}_{4}$ & 0.03 & 0.13 & 0.13 & -0.03 & 0.14 & 0.02 & 0.12 & 0.28 & -0.20 & 0.13 & 1 & & \\
$\mathrm{NO}_{3}$ & -0.47 & $\mathbf{0 . 9 0}$ & $\mathbf{0 . 9 0}$ & -0.18 & 0.48 & $\mathbf{0 . 9 5}$ & $\mathbf{0 . 8 5}$ & 0.49 & 0.31 & $\mathbf{0 . 9 2}$ & -0.16 & 1 & \\
$\mathrm{~F}$ & -0.32 & 0.70 & 0.70 & 0.04 & 0.46 & 0.71 & 0.75 & 0.42 & 0.40 & 0.60 & -0.13 & 0.73 & 1 \\
\hline
\end{tabular}

\#Bold letters depict the strong correlation between the parameters 
Table 6 Pearson's correlation matrix for groundwater samples-Post-monsoon ${ }^{\#}$

\begin{tabular}{llllllllllllll}
\hline & $\mathrm{pH}$ & $\mathrm{EC}$ & $\mathrm{TDS}$ & $\mathrm{TA}$ & $\mathrm{TH}$ & $\mathrm{Na}$ & $\mathrm{K}$ & $\mathrm{Ca}$ & $\mathrm{Mg}$ & $\mathrm{Cl}$ & $\mathrm{SO}_{4}$ & $\mathrm{NO}_{3}$ & $\mathrm{~F}$ \\
\hline $\mathrm{pH}$ & 1 & & & & & & & & & & & \\
$\mathrm{EC}$ & -0.38 & 1 & & & & & & & & & & \\
$\mathrm{TDS}$ & -0.38 & 1.00 & 1 & & & & & & & & & \\
$\mathrm{TA}$ & 0.54 & 0.08 & 0.08 & 1 & & & & & & & & \\
$\mathrm{TH}$ & 0.12 & 0.77 & 0.77 & 0.67 & 1 & & & & & & & \\
$\mathrm{Na}$ & -0.57 & $\mathbf{0 . 9 0}$ & $\mathbf{0 . 9 0}$ & -0.26 & 0.46 & 1 & & & & & & \\
$\mathrm{~K}$ & -0.33 & $\mathbf{0 . 9 0}$ & $\mathbf{0 . 9 0}$ & -0.11 & 0.55 & $\mathbf{0 . 8 4}$ & 1 & & & & & \\
$\mathrm{Ca}$ & 0.04 & $\mathbf{0 . 8 0}$ & $\mathbf{0 . 8 0}$ & 0.54 & $\mathbf{1 . 0 0}$ & 0.57 & 0.69 & 1 & & & & \\
$\mathrm{Mg}$ & 0.22 & 0.52 & 0.52 & 0.78 & $\mathbf{0 . 9 0}$ & 0.21 & 0.24 & 0.76 & 1 & & & \\
$\mathrm{Cl}$ & -0.54 & $\mathbf{0 . 9 0}$ & $\mathbf{0 . 9 0}$ & -0.21 & 0.55 & $\mathbf{0 . 9 7}$ & $\mathbf{0 . 8 4}$ & 0.66 & 0.30 & 1 & & \\
$\mathrm{SO}_{4}$ & -0.16 & 0.15 & 0.15 & -0.16 & 0.05 & 0.04 & 0.19 & 0.16 & -0.10 & 0.15 & 1 & & \\
$\mathrm{NO}_{3}$ & -0.47 & $\mathbf{0 . 9 0}$ & $\mathbf{0 . 9 0}$ & -0.19 & 0.52 & $\mathbf{0 . 9 5}$ & $\mathbf{0 . 8 4}$ & 0.59 & 0.32 & $\mathbf{0 . 9 3}$ & -0.15 & 1 & \\
$\mathrm{~F}$ & -0.49 & $\mathbf{0 . 8 0}$ & $\mathbf{0 . 8 0}$ & -0.07 & 0.54 & $\mathbf{0 . 8 3}$ & $\mathbf{0 . 8 3}$ & 0.61 & 0.34 & $\mathbf{0 . 8 1}$ & 0.15 & $\mathbf{0 . 8 5}$ & 1 \\
\hline
\end{tabular}

\#Bold letters depict the strong correlation between the parameters

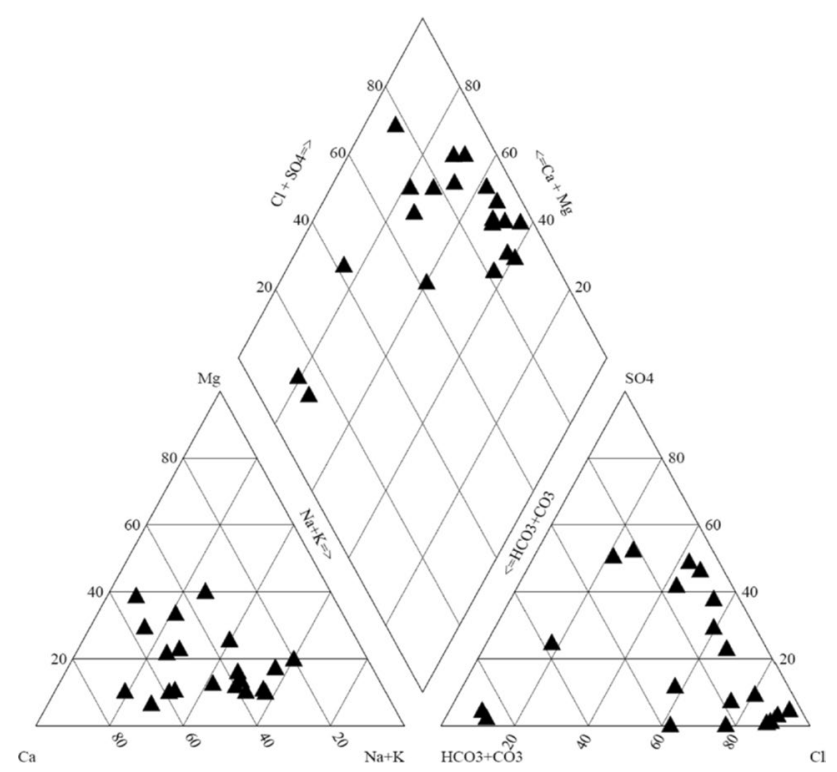

Fig. 6 Piper diagram for the representation of hydrochemical facies of the groundwater-Pre-monsoon

\subsubsection{Chemical nature of the groundwater}

Piper trilinear diagram is a very convenient method to classify the groundwater [37]. This diagram is developed for the groundwater of Shillong for both pre-monsoon (Fig. 6) and post-monsoon (Fig. 7) seasons. It can be seen that during pre-monsoon season, most of the cations are calcium type and sodium and potassium type. Majority of the anions are chloride type, and a few are

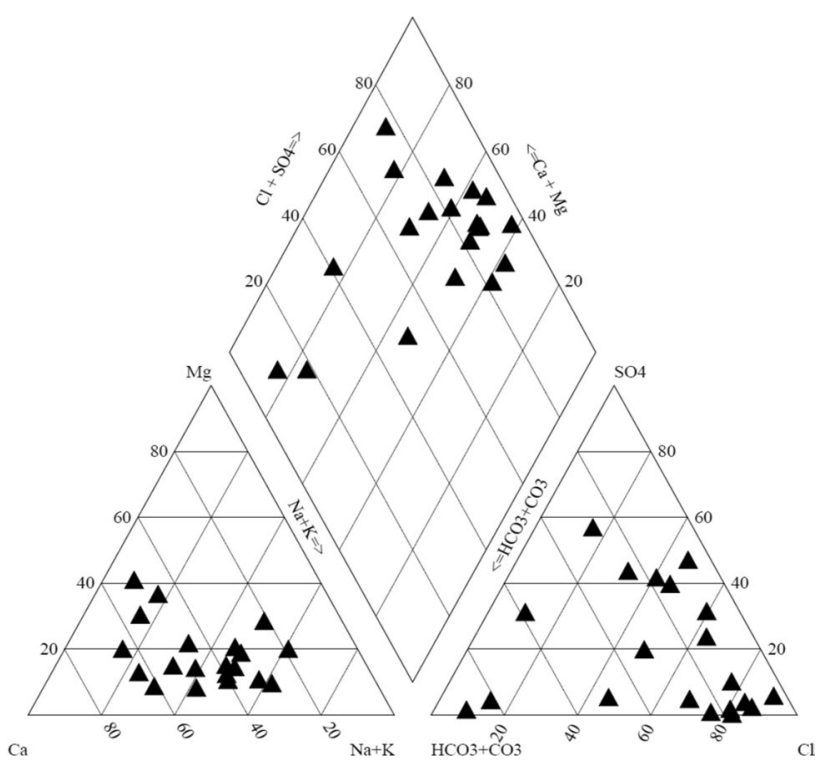

Fig. 7 Piper diagram for the representation of hydrochemical facies of the groundwater-Post-monsoon

bicarbonate type. Similarly, in the post-monsoon season too, most of the cations are calcium type and majority of the anions are chloride type, and a few are bicarbonate type. Thus, seasonal variation does not have much effect on groundwater quality. Overall, groundwater samples are distributed among the calcium chloride and mixedtype hydrochemical facies. 


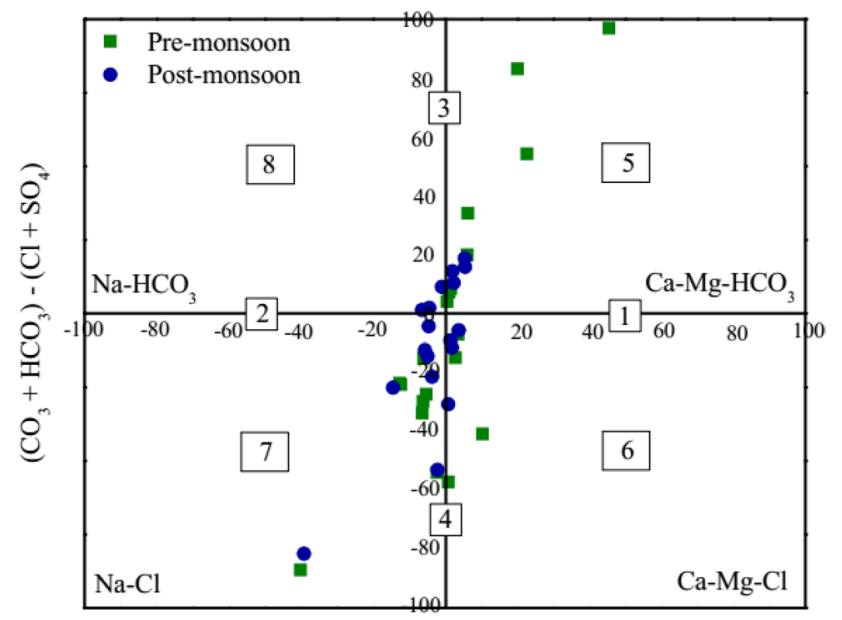

$(\mathrm{Ca}+\mathrm{Mg})-(\mathrm{Na}+\mathrm{K})$

Fig. 8 Chadha's diagram for the representation of hydrochemical facies of the groundwater. (1. Alkaline earths exceed alkali metals, 2. alkali metals exceed alkaline earths, 3 . weak acidic anions exceed strong acidic anions, 4. strong acidic anions exceed weak acidic anions, 5. Ca-Mg- $\mathrm{HCO}_{3}$ type, 6. $\mathrm{Ca}-\mathrm{Mg}-\mathrm{Cl}$ type, 7. $\mathrm{Na}-\mathrm{Cl}$ type, 8. Na$\mathrm{HCO}_{3}$ type)

The findings of Piper diagram can also be corroborated with the Chadha's diagram, as shown in Fig. 8. It can be seen that pre-monsoon samples are distributed among the three hydrochemical facies, viz. Ca-Mg$\mathrm{HCO}_{3}$ type, $\mathrm{Na}-\mathrm{Cl}$ type, and $\mathrm{Ca}-\mathrm{Mg}-\mathrm{Cl}$ type. However, the post-monsoon samples are more or less equally distributed among the four facies, viz. $\mathrm{Ca}-\mathrm{Mg}-\mathrm{HCO}_{3}, \mathrm{Na}-\mathrm{Cl}$, $\mathrm{Ca}-\mathrm{Mg}-\mathrm{Cl}$, and $\mathrm{Na}-\mathrm{HCO}_{3}$, and hence, such groundwater may be called as the mixed type.

\subsubsection{Gibbs diagram and rock-water interaction}

To understand the mechanism of factors governing groundwater chemistry of Shillong, it is necessary to understand the Gibbs diagram [38]. Gibbs diagrams have been plotted for both cations and anions during pre- and post-monsoon seasons, as shown in Fig. 9. It is quite evident that during pre-monsoon as well as postmonsoon seasons, the rock dominance and atmospheric precipitation are the two most important mechanisms which are affecting the ionic concentration in groundwater of Shillong [38]. It is known that the important cations in groundwater are $\mathrm{Na}, \mathrm{K}$, and $\mathrm{Ca}$, while anions are the $\mathrm{Cl}$ and $\mathrm{SO}_{4}$. Therefore, the relation between these ions and TDS is reflecting that the water is in partial equilibrium with the rocky content of the region [38]. Moreover, as Meghalaya is one of the most heavily down poured regions of India, the dominance of atmospheric precipitation mechanism is very much obvious. It also indicates that the chemical constituents in the groundwater are influenced by the dissolved salts which are obtained from atmospheric precipitation.

These diagrams indicate that rock weathering in the region is not the major mechanism controlling the chemistry of the groundwater. Rather, the composition of dissolved salts is influenced by the atmospheric precipitation as well.

\subsubsection{Mode of weathering and identification of hydrogeochemical processes}

Gibbs diagram reflected that rock weathering is one of the factors responsible for controlling the groundwater chemistry apart from atmospheric precipitation. Therefore, it is important to explore the weathering process. Scatter diagram of $(\mathrm{Ca}+\mathrm{Mg})$ vs. $\left(\mathrm{HCO}_{3}+\mathrm{SO}_{4}\right)$ in Fig. 10a shows that the samples lie near the equiline in carbonate weathering zone both during the pre-monsoon and post-monsoon seasons. It shows that carbonate weathering is the predominant mechanism affecting the Shillong's groundwater. To determine the rock types of $\mathrm{Ca}$ and $\mathrm{Mg}$ involved in the weathering process, ratio of $\mathrm{Ca} / \mathrm{Mg}$ is calculated. $\mathrm{Ca} / \mathrm{Mg}$ ratio of unity denotes the dissolution of dolomite rocks, while higher ratios indicate the dominance of calcite rocks $[4,39]$. Further higher ratios of $\mathrm{Ca} / \mathrm{Mg}$, viz. $\mathrm{Ca} / \mathrm{Mg}>2$, represent the dissolution of silicate minerals in the groundwater [40]. The $\mathrm{Ca} / \mathrm{Mg}$ ratio in groundwater of Shillong district shows the weathering of silicate minerals in the rocks as both the pre-monsoon and post-monsoon samples lie above the $\mathrm{Ca} / \mathrm{Mg}$ ratio of 2 .

\section{Conclusion}

The study was carried out to assess the suitability of groundwater of Shillong region in India for drinking and irrigation purposes and to understand various hydrochemical processes involved. It was found that groundwater in the region is acidic in nature along with having 

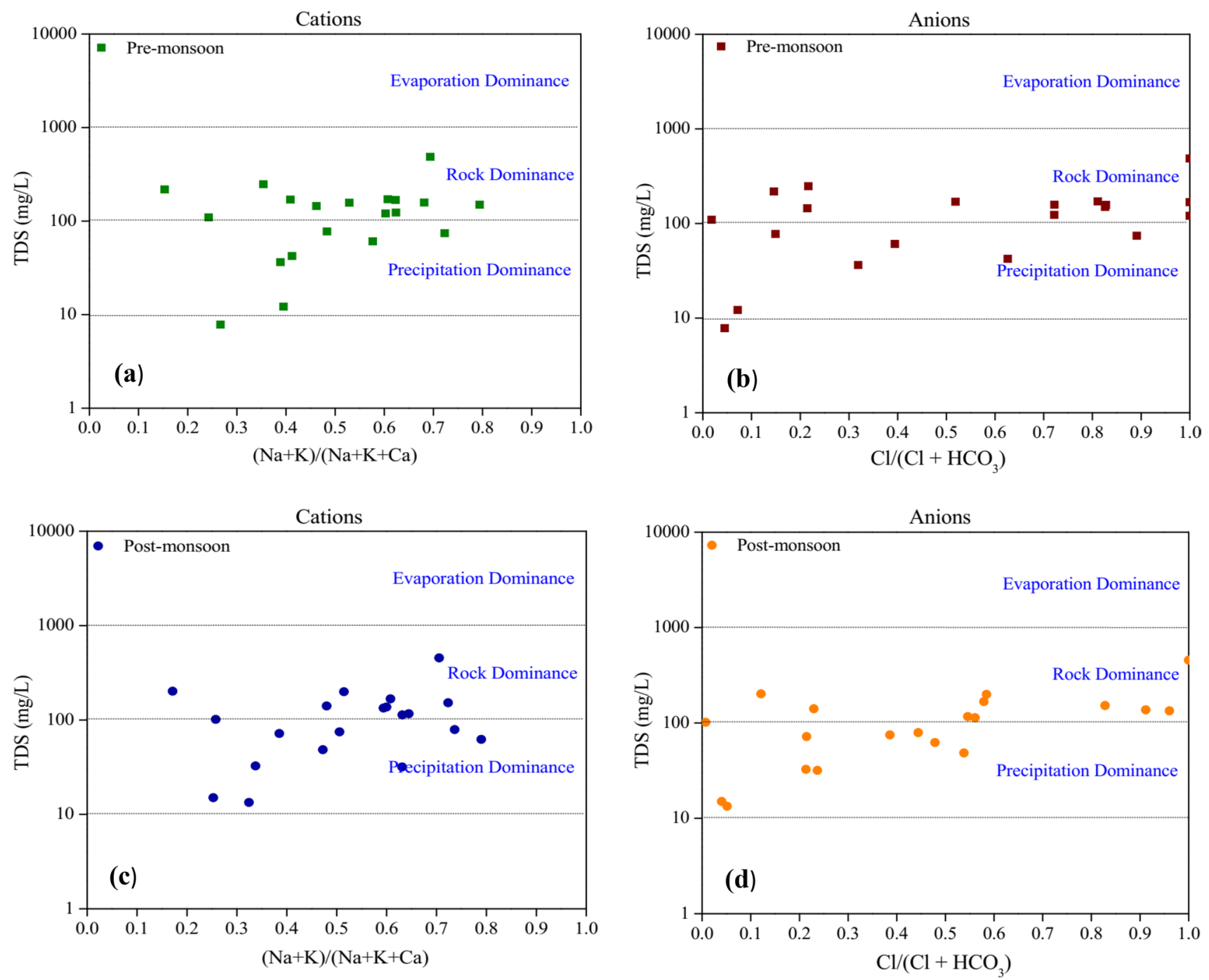

Fig. 9 a-d Gibbs plots, depicting the mechanisms controlling groundwater chemistry in Shillong

high concentration of nitrate. Iron and manganese were also found in high amount. Among the metals, nickel, mercury, and cadmium were in high concentration in some of the samples which is an issue of concern. Anthropogenic factors could be attributed to the high concentration of these parameters. Consumption of water contaminated with such metals might result in variety of health ailments, and therefore, its utilization for drinking without necessary treatment is not recommended. However, adoption of suitable removal technologies, such as oxidation/filtration, might help in improving the water quality. Moreover, the water quality in the region was found suitable for agricultural purposes in respect of all the parameters except magnesium ratio and corrosivity ratio. The variation in the groundwater samples of pre-monsoon and post-monsoon seasons was found minimal. Hydrochemical studies inferred that the groundwater in the region is influenced by the rock weathering along with the atmospheric precipitation considering that Meghalaya is the highest down poured state in India. 

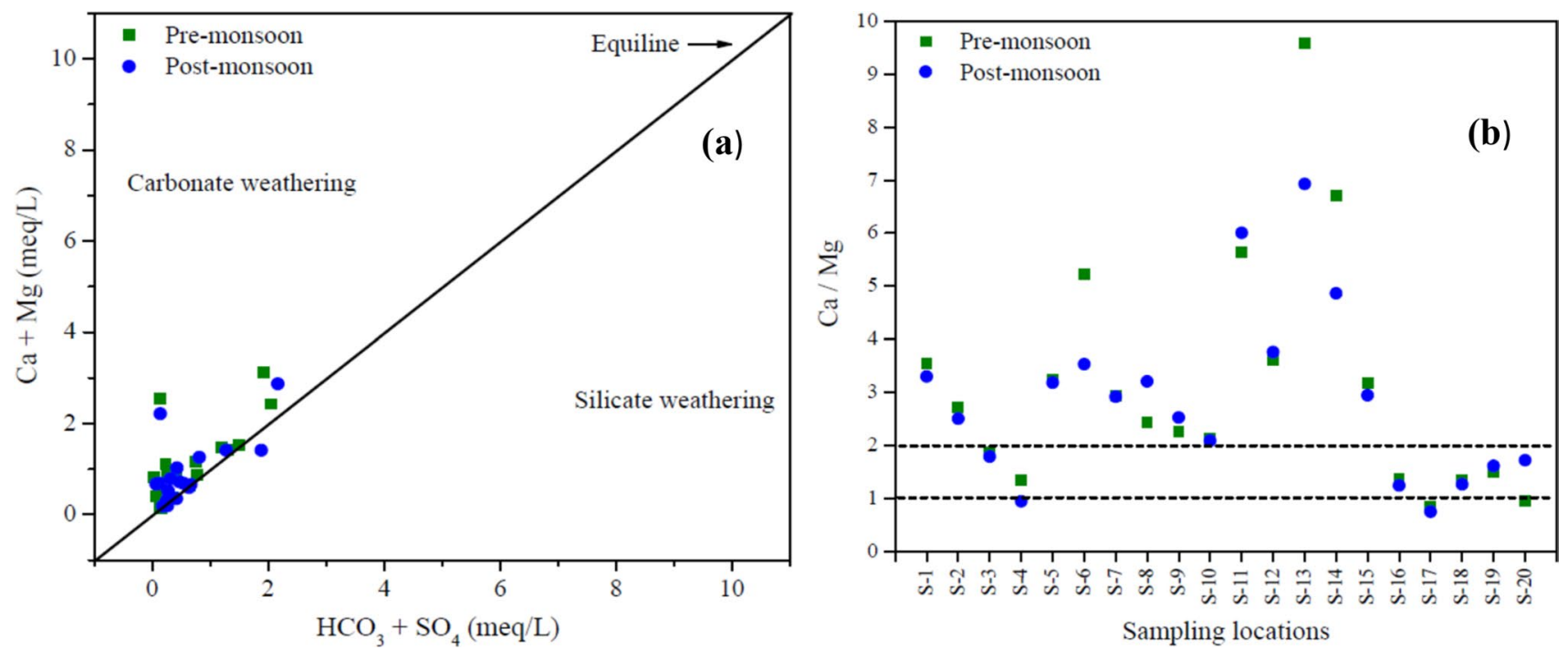

Fig. 10 a-b Mode of weathering in groundwater of Shillong representing that carbonate weathering is the predominant mechanism

Availability of data and material Data are available upon request to corresponding author Surya Singh (suryasingh.er@gmail.com).

Code availability Not applicable.

\section{Compliance with ethical standards}

Conflict of interest Authors declare no conflicts of interest.

Ethical approval Not applicable.

Open Access This article is licensed under a Creative Commons Attribution 4.0 International License, which permits use, sharing, adaptation, distribution and reproduction in any medium or format, as long as you give appropriate credit to the original author(s) and the source, provide a link to the Creative Commons licence, and indicate if changes were made. The images or other third party material in this article are included in the article's Creative Commons licence, unless indicated otherwise in a credit line to the material. If material is not included in the article's Creative Commons licence and your intended use is not permitted by statutory regulation or exceeds the permitted use, you will need to obtain permission directly from the copyright holder. To view a copy of this licence, visit http://creativecommons .org/licenses/by/4.0/.

\section{References}

1. Wu J, Li P, Wang D, Ren X, Wei M (2020) Statistical and multivariate statistical techniques to trace the sources and affecting factors of groundwater pollution in a rapidly growing city on the Chinese Loess Plateau. Human Ecol Risk Assess 26:1603-1621. https://doi.org/10.1080/10807039.2019.15941 56

2. Zhou Y, Li P, Chen M, Dong Z, Lu C (2020) Groundwater quality for potable and irrigation uses and associated health risk in southern part of Gu'an county, North China Plain. Environ Geochem Health. https://doi.org/10.1007/s10653-020-00553-y

3. World Bank Report (2012) available at http://www.worldbank. org/en/news/feature/2012/03/06/india-groundwater-criticaldiminishing. Accessed 24 January 2020.

4. Jain CK, Sharma SK, Singh S (2018) Physico-chemical characteristics and hydrogeological mechanisms in groundwater with special reference to arsenic contamination in Barpeta district, Assam (India). Env Monit Assess 190:1-17. https://doi. org/10.1007/s10661-018-6781-5

5. Jain CK, Singh S (2019) Best management practices for agricultural non-point source pollution: policy interventions and way forward. World Water Pol 5(2):207-228. https://doi.org/10.1002/ wwp2.12015

6. Wu J, Zhang Y, Zhou H (2020) Groundwater chemistry and groundwater quality index incorporating health risk weighting in Dingbian county, Ordos basin of Northwest China. Geochemistry. https://doi.org/10.1016/j.chemer.2020.125607

7. He S, Wu J (2019) Hydrogeochemical characteristics, groundwater quality, and health risks from hexavalent chromium and nitrate in groundwater of Huanhe formation in Wuqi county, Northwest China. Expo Health 11:125-137. https://doi. org/10.1007/s12403-018-0289-7

8. He X, Wu J, He S (2019) Hydrochemical characteristics and quality evaluation of groundwater in terms of health risks in Luohe aquifer in Wuqi county of the Chinese Loess Plateau, Northwest China. Human Ecol Risk Assess 25:32-51. https:// doi.org/10.1080/10807039.2018.1531693

9. Wu J, Zhou H, He S, Zhang Y (2019) Comprehensive understanding of groundwater quality for domestic and agricultural purposes in terms of health risks in a coal mine area of the Ordos basin, north of the Chinese Loess Plateau. Environ Earth Sci 78:446. https://doi.org/10.1007/s12665-019-8471-1

10. Su H, Kang WD, Xu YJ, Wang J (2016) Assessment of groundwater quality and health risk in the oil and gas field of Dingbian county. Northwest China Expo Health 9:227-242. https://doi. org/10.1007/s12403-016-0234-6

11. Abdalla O, Al-Abri RY (2014) Factors affecting groundwater chemistry in regional arid basins of variable lithology: example of Wadi Umairy, Oman. Arab J Geosci 7:2861-2870. https://doi. org/10.1007/s12517-013-0981-7 
12. Li P, He S, Yang N, Xiang G (2018) Groundwater quality assessment for domestic and agricultural purposes in Yan'an City, northwest China: implications to sustainable groundwater quality management on the Loess Plateau. Environ Earth Sci 77:775. https://doi.org/10.1007/s12665-018-7968-3

13. Kachari $R$ (2019) Swelter in the city: population distribution, land use change and the urban heat island effect in Shillong, India. In: Saikia A, Thapa P (eds) Environmental change in the Himalayan region. Springer, Cham, pp 173-187

14. CGWB (2013) Ground water information booklet. East Khasi Hills District, Meghalaya, Central Ground Water Board, North East Region, Guwahati, India, September, p 2013

15. Jain CK, Bhatia KKS (1988) Physico-chemical Analysis of Water and Wastewater, User's Manual. UM-26, National Institute of Hydrology, Roorkee.

16. APHA (1992) Standard methods for the examination of water and waste waters, 18th edn. Am Pub Healh Asso, Washington, DC

17. BIS (2012) Specifications for drinking water. IS: 10500:2012. Bureau of Indian Standards, New Delhi, India

18. WHO (2011) Guidelines for drinking water quality, 4th edn. World Health Organization, Geneva, Switzerland

19. Nayak B (2013) Mineral matter and the nature of pyrite in some high-sulphur tertiary coals of Meghalaya, Northeast India. J Geol Soc India 81:203-214. https://doi.org/10.1007/s1259 4-013-0023-9

20. Barooah PK, Baruah MK (1996) Sulphur in Assam coal. Fuel Process Technol 46:83-97. https://doi.org/10.1016/03783820(95)00058-5

21. Yin R, Fan C, Sun J, Shang C (2018) Oxidation of iron sulphide and surface-bound iron to regenerate granular ferric hydroxide for in-situ hydrogen sulphide control by persulfate, chlorine, and peroxide. Chem Engg J 336:587-594. https://doi.org/10.1016/j. cej.2017.12.060

22. Swer S, Singh OP (2004) Status of water quality in coal mining areas of Meghalaya, India. Proceedings of the National Seminar on Environmental Engineering with special emphasis on Mining Environment, NSEEME-2004, 19-20.

23. Gad M, Dahab K, Ibrahim H (2016) Impact of iron concentration as a result of groundwater exploitation on the Nubian sandstone aquifer in El Kharga Oasis, western desert Egypt. NRIAG J Astro Geophy 5:216-237. https://doi.org/10.1016/j.nrjag .2016.04.003

24. World Health Organization (WHO) (2003) Iron in drinking water, Background document for development of WHO guidelines for drinking water quality. WHO/SDE/WSH/03.04/08.

25. World Health Organization (WHO) (2011) Manganese in drinking water, Background document for development of WHO guidelines for drinking water quality. WHO/SDE/WSH/03.04/104/ Rev/1.

26. Jain CK, Vaid U, Sharma SK, Singh S (2019) Assessment of potentially toxic elements' contamination in surface soils of Kulsi
River Basin in North East India. SN Appl Sci 1:673. https://doi. org/10.1007/s42452-019-0689-8

27. Wilcox $L$ (1955) Classification and use of irrigation waters (No. 969). US Department of Agriculture, Washington

28. Richards LA (1954) Diagnosis and improvement of saline and alkali soils. agricultural handbook No 60. United States Department of Agriculture, Washington DC

29. Doneen ID (1961) The influence of crop and soil on percolating water. Proc Biannu Conf Groundw Recharge 1961:156-163

30. Kelly WP, Brown SM, Liebig GF (1940) Chemical effects of saline irrigation water on soils. Soil Sci 49(2):95-108

31. Szabolcs I, Darab C (1964) The influence of irrigation water of high sodium carbonate content of soils. Proceedings of 8th international congress of ISSS, transmission, 2. 803-812.

32. Lloyd JW, Heathcote JA (1985) Natural inorganic hydrochemistry in relation to ground water. University of Wisconsin Madison, Oxford Science Publications, United States. ISBN 9780198544227

33. Tripathi AK, Mishra UK, Mishra A, Tiwari S, Dubey P (2012) Studies of hydrogeochemical in groundwater quality around Chakghat area, Rewa district, Madhya Pradesh, India. Int J Modern Eng Res 2(6):4051-4059

34. Karanth KR (1987) Groundwater assessment, development and management. Tata-McGraw- Hill Education, New Delhi

35. Zhou Y, Li P, Xue L, Dong Z, Li D (2020) Solute geochemistry and groundwater quality for drinking and irrigation purposes: a case study in Xinle city, North China. Geochemistry. https:// doi.org/10.1016/j.chemer.2020.125609

36. Kumar M, Kumari K, Ramanathan AL, Saxena R (2007) A comparative evaluation of groundwater suitability for irrigation and drinking purposes in two intensively cultivated districts of Punjab, India. Env Geol 53:553-574. https://doi.org/10.1007/s0025 4-007-0672-3

37. Piper AM (1944) A graphical procedure in the geochemical interpretation of water analysis. Trans Am Geophys Union 25:914928. https://doi.org/10.1029/TR025i006p00914

38. Gibbs RJ (1970) Mechanisms controlling world water chemistry. Science 170(3962):1088-1090. https://doi.org/10.1126/scien ce.170.3962.1088

39. Mayo AL, Loucks MD (1995) Solute and isotopic geochemistry and groundwater flow in the central Wasatch range, Utah. J Hydrol 172:31-59. https://doi.org/10.1016/0022-1694(95)02748 $-\mathrm{E}$

40. Katz BG, Tyler BC, Thomas DB, Davis JH (1997) Use of chemical and isotopic tracers to characterize the interactions between groundwater and surface water in mantled karst. Ground Water 35:1014-1028. https://doi.org/10.1111/j.1745-6584.1997.tb001 74.x

Publisher's Note Springer Nature remains neutral with regard to jurisdictional claims in published maps and institutional affiliations. 